\title{
Fertility and Marital Status Changes over the Life Cycle: a Comparative Study of Finland and Austria
}

\author{
WOLFGANG LUTZ
}

Deputy Program Leader, Docent

Population Program, IIASA, Austria

DOUGLAS WOLF

Program Director, Population Dynamics Program

The Urban Institute, Washington D.C., USA and IIASA, Austria

\section{Introduction}

In recent decades there have been profound changes in patterns of marriage, divorce, fertility, and mortality in many industrialized nations. Yet the implications of these changes for the future structure of families and households remain uncertain. What, for example, is the probability that under current rates a marriage will ultimately end in divorce; how does this depend on age at marriage, duration of marriage, the number of children born and the timing of births; and, what are the subsequent average waiting times until remarriage or death?

Complex questions of this kind cannot be fully answered using traditional tools of family demography, such as the family life cycle concept (see, for example, Glick, 1957 ; 1977) or separate analyses of marriage, divorce, and fertility. More comprehensive models must be developed. In principle there seem to be two possible approaches: microsimulation and the multi-state life table (MSLT) analysis. ${ }^{1}$ The micro-simulation approach operates at the individual level, and entails generating a sample of individuals whose life cycle behavior is determined by specified transition intensities (see, for example, Wolf, 1986). The multi-state approach, in contrast, operates on an aggregate level, using generalized life table techniques. The MSLT is a useful descriptive tool which under certain assumptions can also be used for projection. It has been used in several studies of the marriage life cycle (Espenshade, 1986; Willekens et al., 1982; Wijewickrema and Alii, 1984; Lutz, 1985) and in fertility analysis (Suchindran et al., 1977; Suchindran and Koo, 1980). In the present paper we study family dynamics by using extensions of the usual MSLT approach. First, we consider both parity and marital status changes, both singly and in combination. Second, we allow some of the transition rates to vary by duration of exposure to risk as well as age.

The remainder of this paper is organized as follows. Section 2 discusses conceptual issues and presents the methodology, including the extension to duration of exposure in addition to age as a time dimension. Section 3 highlights selected empirical findings for Finland (1984) and Austria (1981 - 85), while section 4 discusses possible future extensions and applications of the family status MSLT methodology.

1 An additional approach, which generalizes the MSLT along similar lines to that used here, but with a different mathematical technique, can be found in Rajulton (1985). 


\section{Methods and Data}

Conceptual Issues. The first step in defining a MSLT model is to define the state space. This is a critical step since it determines the size and complexity of the model, and consequently the volume of information generated during computation of the model's output. In the case of marital-status dynamics, two key issues are the number of marital categories distinguished, and whether or not marriage order is incorporated.

There are four basic marital categories: single (never-married), married, widowed and divorced. These categories are, in general, distinguished on legalistic grounds; i.e. does a legal marriage exist, or has a divorce been formally granted. However, statuses differentiated on behavioral rather than legalistic grounds are also possible, and have been used in some studies. For example, "cohabitation» is, in effect, a marital status and is of growing importance in several European countries (see Keilman, 1987). Similarly, »separated» is a marital status which may be occupied between marriage and divorce, and which may even be further subdivided into formal (legally recognized) and informal variants.

The complexity of the state space used in our analysis is to some extent dictated by data availability. In particular, since one of our data sources is a population registry, and hence employs legal rather than behaviorally-derived statuses, we confine ourselves to the four categories single, married, widowed and divorced. Also, since we distinguish women according to parity, in order to keep the model manageable we disregard marriage order.

In our data for Finland, we employ a 12-state model with statuses designated as follows: $\mathrm{s} 0$ and $\mathrm{s} 1+$ (single, with 0 and one or more children, respectively); $\mathrm{m} 0, \mathrm{~m} 1$, $\mathrm{m} 2, \mathrm{~m} 3$, and $\mathrm{m} 4+$ (married, with the indicated number of children); w0 and $\mathrm{w} 1+$ (widowed); and d0, d1 and d $2+$ (divorced). In our analysis of Austrian data, we also use a 12-state model, but with slightly different states ( $\mathrm{m} 3$ and $\mathrm{m} 4+$ are collapsed into $\mathrm{m} 3+$; $\mathrm{w} 1+$ is expanded into $\mathrm{w} 1$ and $\mathrm{w} 2+$ ).

Having defined the state space, it is necessary to indicate which flows between states are possible. The possible flows found in our model for Finland are illustrated in Figure 1, in matrix form. The columns of this matrix designate origin states, while

Figure 1. Illustration of potential transitions: marital/parity status life table for Finland, 1984.

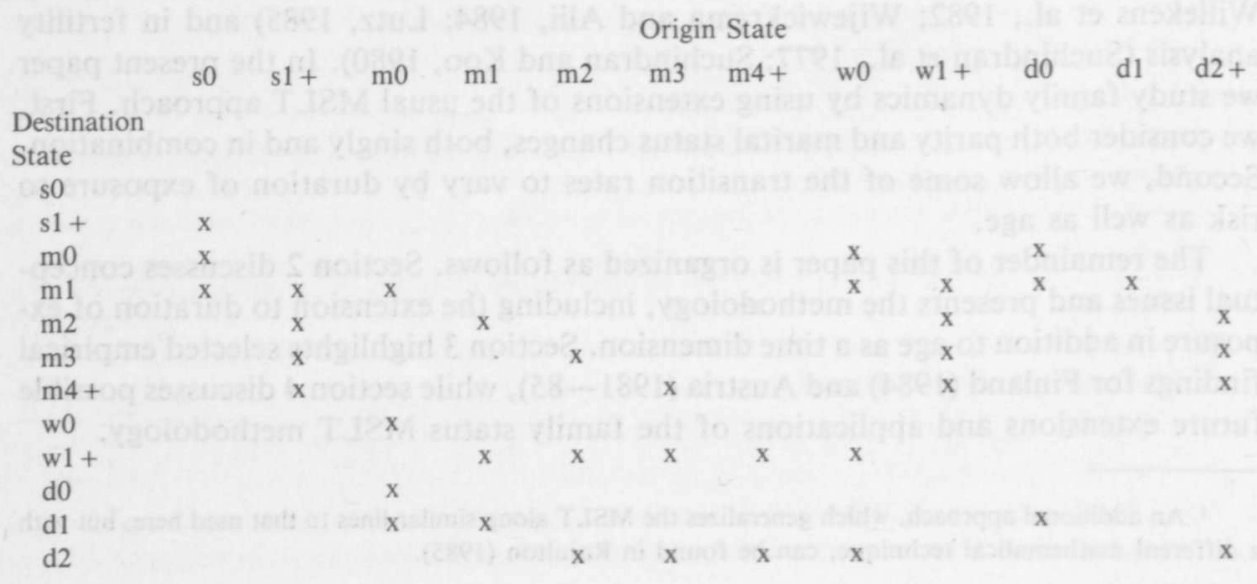


the rows designate destination states; an $\mathrm{x}$ indicates a possible origin-destination pair. Not shown are transitions to the absorbing state »dead», which are of course possible from all origin states. Note that in some cases (such as movement from single to married) it is possible to change only marital status, or only parity, or to change both marital status and parity simultaneously. The corresponding matrix of possible flows in our model for Austria is very similar to Figure 1, and therefore is not shown.

Methods. Our basic model is the MSLT described in several sources including Keyfitz (1986), Rogers and Willekens (1986), and Willekens et al. (1982). In our application, there is for each age a matrix of transition rates (times -1) arranged as in Figure 1 ; in addition the main diagonal of the matrix contains the sum of (1) the death rate (in state $j$ ) at age $\mathrm{x}$ and (2) the sum of the corresponding column entries. Denote this matrix $M(\mathrm{x})$. Then, if $l(\mathrm{x})$ represents the array of proportions (or numbers) of the population in each status at exact age $x$, the corresponding array at exact age $\mathrm{x}+1$ is

$l(\mathrm{x}+1)=\left(I+\frac{M(\mathrm{x})}{2}\right)^{-1}\left(I-\frac{M(\mathrm{x})}{2}\right) l(\mathrm{x})$

We also present some findings from a »duration-dependent multistate life table» (DDMSLT). In the DDMSLT individuals are classified by duration-category (less than one year, 1-2 years, and so on, in their current status) as of each birthday. This model requires, at each age, a sequence of matrices $M \Delta(\mathrm{x}), M_{0}(\mathrm{x}), M_{1}(\mathrm{x}), \ldots$, $M_{\mathrm{x}}(\mathrm{x})$, each of which is in the same form as for the usual MSLT. The subscripts $\Delta, 0,1, \ldots$ refer to duration categories. Duration category $\Delta$ is the category entered if a transition occurs between ages $\mathrm{x}$ and $\mathrm{x}+1$.

For purposes of computation, these matrices are arranged as follows:

$$
M^{*}(\mathrm{x})=\left[\begin{array}{cccccc}
M_{\Delta}(\mathrm{x}) & C M_{0}(\mathrm{x}) & C M_{1}(\mathrm{x}) & C M_{2}(\mathrm{x}) & \ldots & C M_{x}(\mathrm{x}) \\
0 & D M_{0}(\mathrm{x}) & 0 & 0 & \ldots & 0 \\
0 & 0 & D M_{1}(\mathrm{x}) & 0 & \ldots & 0 \\
0 & 0 & 0 & D M_{2}(\mathrm{x}) \ldots & 0 \\
. & . & . & . & . & . \\
. & . & . & . & . & . \\
. & . & . & . & . & . \\
0 & 0 & 0 & 0 & \ldots & D M_{\mathrm{x}}(\mathrm{x})
\end{array}\right]
$$

where $D M_{\mathrm{d}}(\mathrm{x})$ is a matrix containing the principal diagonal of $M_{d}(\mathrm{x})$, and $C M_{d}(\mathrm{x})$ is the matrix $M_{d}(\mathrm{x})$ with its main diagonal elements replaced by zeros. Further details about this approach can be found in Wolf (1988).

Data. We employ two sets of data that have a similar structure but are of quite different origin. For Finland the study is based on a complete record of all family status transitions during the year 1984 . The transition rates were extracted from the Finnish population register and were classified according to marital status, parity, age, and duration in status as of January 1, 1984. All rates are for single years of age. The Finnish data were also used to calculate duration-dependent rates, using for all transitions out of marriage (at any parity) the duration categories $0,1, \ldots$, $15+$ years; and for all transitions out of divorce the categories $0,1, \ldots, 5+$ years. Minor inconsistenciens in the data were adjusted to match the officially published vital statistics.

In the case of Austria, the rates come from a 1 percent micro-census survey conducted in 1986. The Austrian survey contains fertility and marital status histories for all women aged 16 to 60 at the time of the survey. After removing some apparent inconsistencies from the data by either correcting them or removing the cases from the data, complete records for 14,500 women were given that should be representa- 
tive for Austria. ${ }^{2}$ In order to increase the number of observations the experience of the last five years (1981 - 85) was aggregated by assuming independence of individual transition probabilities over those years and simply summing up the number of transitions and the person years of exposure in the various states in those five years.

Since the Finnish data pertain to the entire population, the corresponding rates display more regular and stable patterns than do those for Austria.

It also must be noted that we consider only the 35 -year period from exact age 15 to exact age 50, that is, the portion of the lifetime during which childbearing takes place. We assume that neither childbearing nor first marriage take place before the 15 th birthday. For this reason the life tables given will also end at age 50 and all life expectancies given will refer to the years lived up to age 50 and not till the end of life as in the ordinary life table. Due to the lack of status-specific mortality rates mortality between ages 15 and 50 in all states was assumed to correspond to the official life tables for the total female population.

\section{Empirical Findings: Austria, 1981-85, and Finland, 1984}

The output from the model described in the previous section consists of very extensive tables providing the probabilities of being in any state at any age, given that one was in a specified state at a specified earlier age. In our case this $l(\mathrm{x})$ table alone could provide 90720 probabilities [(12 states of origin*12 states of destination*35 ages $)+(12 * 12 * 34$ ages $)+\ldots$. . Another interesting set of output tables provides the average times expected to be spent in any status (life expectancies) given that one was in an specified status at a specified age. In our case we would get a maximum of 5040 life expectancies $(12 * 12 * 35)$.

Because of this huge amount of potential output we have selected only a few probabilities and life expectancies that are indicative for certain relevant questions. The following selection of findings will be organized around five questions. Tables 1 to 5 correspond to those questions; the »a»-tables always refer to Finland, the »b"-tables to Austria.

\section{How does premarital childbearing influence a woman's later marital status?}

In Finland unmarried 20-year-old women with one or more children have a slightly higher chance of remaining unmarried at ages 30 through 50 than do childless unmarried women of the same age. This difference becomes even greater when looking at the subsequent marital status of women unmarried at ages 25 and 30 . Almost half of all unmarried women with children at age 25 can expect to be still unmarried at age 40; for childless unmarried women the corresponding figure is only 38 percent. With respect to the future prospects for marriage it also seems to make quite a difference if a woman is single at age 25 or at age 30 . These five years increase the probability of remaining single at age 50 by more than 20 percentage points. The pattern of proportions married and single are complimentary. Single women without children at all ages shown in Table 1a have a slightly higher probability of being in the divorced state at ages 30 through 50 , but this results from a combination of differing marriage and divorce probabilities.

\footnotetext{
2 See Aufhauser and Lutz (1987) for more detail concerning the data of this survey.
} 
Table 1a. How does a non-marital birth influence a woman's later marital status (Finland 1984)?

Status at age 20

Single, no children
Status at age 25

Single,
ningle,
children
Status at age 30

Single, Single,

\begin{tabular}{lllllll} 
Age & \multicolumn{7}{c}{ Proportions Single at age $30,40,50$ (in percent) } \\
30 & 38.38 & 39.84 & 58.24 & 68.84 & - & - \\
40 & 25.29 & 28.04 & 38.09 & 48.45 & 64.82 & 70.39 \\
50 & 22.29 & 24.72 & 33.58 & 42.72 & 57.15 & 62.06
\end{tabular}

Age

$\begin{array}{ll}30 & 58.85\end{array}$

$40 \quad 67.25$

$\begin{array}{ll}50 & 63.67\end{array}$

Age

30

40

50

Proportions Married at ages 30, 40, 50 (in percent)

$\begin{array}{llllc}57.47 & 40.35 & 30.49 & - & - \\ 65.59 & 55.79 & 47.93 & 31.79 & 27.98 \\ 62.80 & 54.03 & 48.53 & 33.90 & 32.30\end{array}$

Proportions Divorced at ages 30, 40, 50 (in percent)

$\begin{array}{lrrrr}2.04 & .93 & .45 & - & - \\ 4.36 & 3.95 & 2.36 & .33 & .23 \\ 6.33 & 5.73 & 3.92 & 1.05 & 85\end{array}$

Table 1b. How does a pre-marital birth influence a woman's later marital status (Austria 1981-1985)?

\begin{tabular}{ccccc}
\multicolumn{2}{c}{ Status at age 20} & \multicolumn{2}{c}{ Status at age 25} & \multicolumn{2}{c}{ Status at age 30} \\
$\begin{array}{c}\text { Single, } \\
\text { no children }\end{array}$ & $\begin{array}{c}\text { Single, } \\
\text { children }\end{array}$ & $\begin{array}{c}\text { Single, } \\
\text { no children }\end{array}$ & $\begin{array}{c}\text { Single, } \\
\text { children }\end{array}$ & $\begin{array}{c}\text { Single, } \\
\text { no children }\end{array}$
\end{tabular}

\begin{tabular}{|c|c|c|c|c|c|c|}
\hline Age & \multicolumn{6}{|c|}{ Proportions Single at ages $30,40,50$ (in percent) } \\
\hline 30 & 31.13 & 12.03 & 57.54 & 46.57 & - & - \\
\hline 40 & 19.58 & 6.10 & 37.10 & 23.63 & 66.45 & 50.75 \\
\hline 50 & 17.18 & 4.80 & 32.91 & 18.60 & 59.68 & 39.94 \\
\hline
\end{tabular}

Age

$30 \quad 64.21$

$40 \quad 70.09$

65.22

Proportions Married at ages 30, 40, 50 (in percent)

$50 \quad 65.22$

$\begin{array}{ll}82.20 & 40.65 \\ 82.21 & 55.49 \\ 75.91 & 52.87\end{array}$

51.46

67.92

65.68

30.29

31.68

44.53

49.28

Age

$\begin{array}{ll}30 & 3.60 \\ 40 & 7.29 \\ 50 & 9.02\end{array}$

Proportions Divorced at ages 30, 40, 50 (in percent)

$\begin{array}{lllll}4.16 & 1.39 & 1.39 & - & - \\ 7.91 & 5.56 & 5.72 & 1.99 & 2.97 \\ 9.87 & 6.81 & 7.80 & 3.15 & 4.62\end{array}$

For Austria the picture looks very different. In contrast to Finland a premarital birth strongly increases the probability of being married at a later age. 82 percent of all single women aged 20 who already have a child will be married at age 30 whereas the percentage for the childless 20 -year-olds in only 64 percent. This general pattern holds for all ages of origin and ages of observation. Among 30-year-old single women with a child, 50 percent will be married at age 50 , compared to only 32 percent of the childless women. Also in contrast to Finland, single women with children have a slightly higher probability of being in the divorced states than childless women. This, however, might be explained by higher proportions marrying. 
This strong difference between Finland and Austria in the way a premarital birth affects the probabilities of being married at a later age seems to reveal a major cultural difference between the two countries. Austria has a tradition of a very high proportion of illegitimate births. Between 1860 and 1930 the proportion of illegitimate births averaged around 25 percent (Haslinger, 1982). After a temporary low during the time of the baby boom in the 1960 s the proportion of illegitimate births recently increased again to a level of above 20 percent. In certain districts of Austria it is above 40 percent. One aspect of this pattern of illegitimacy is that the proportions of women marrying after one or even several premarital births is very high. This may partly go back to a traditional rural pattern where the heir of a farm wanted to be sure that his future wife was fertile (see Kytir and Münz, 1986). But it also reflects the fact that in today's Austrian society it is not accepted, and also financially very difficult, for a single woman to rear her children alone. In Finland, these things seem to be different; on the one hand, illegitimate births seem to be less accepted than in Austria, but on the other hand it is easier for a single mother to bring up her children without being married.

\section{How does the number of children for married women affect the probability of being divorced at later ages?}

Finland shows a U-shaped relationship between the number of children and proportion divorced at ages 40 and 50. Married women with no children at ages 25 or 35 have the highest probabilities of later being divorced. Their probability of ever getting a divorce is probably significantly higher, since the following table shows that childless women also have the highest remarriage probabilities. The same is true in Austria. In order to remove the influence of differential remarriage probabilities and look at divorce probabilities rather than probabilities of being in the divorced state at the same age, one may simply chain together the age-specific divorce probabilities for women of different parities; for Austria this shows that childless marriages tend to end in divorce in 38 percent in the cases, marriages with one child in 28 percent of the cases, with two children in 20 percent of the cases, and with three or more children in only 15 percent of the cases.

Hence the main difference between Finland and Austria lies in the fact that in Austria the data clearly imply that the lower the number of children for 25-year-old married women, the higher the probability of divorce and also the probability of being in the divorced state at later ages, while in Finland the lowest divorce proba-

Table 2a. How does the number of children for married women affect the probability of being divorced at certain ages (Finland 1984)?

Proportions Divorced at ages 30, 40, 50 (in percent)

\begin{tabular}{|c|c|c|c|c|c|}
\hline \multirow[b]{2}{*}{ Age } & \multicolumn{5}{|c|}{ Status at age 25} \\
\hline & $\begin{array}{l}\text { Married, } \\
\text { no children }\end{array}$ & $\begin{array}{c}\text { Married, } \\
1 \text { child }\end{array}$ & $\begin{array}{l}\text { Married, } \\
2 \text { children }\end{array}$ & $\begin{array}{l}\text { Married, } \\
3 \text { children }\end{array}$ & $\begin{array}{c}\text { Married, } \\
4+\text { children }\end{array}$ \\
\hline 30 & 3.55 & 2.70 & 2.37 & 2.35 & 1.72 \\
\hline 40 & 7.57 & 6.22 & 5.88 & 6.24 & 6.21 \\
\hline 50 & 9.89 & 8.73 & 8.63 & 9.27 & 9.45 \\
\hline & & & tatus at age & & \\
\hline 40 & 5.27 & 3.33 & 2.27 & 2.28 & 2.80 \\
\hline 50 & 9.11 & 6.39 & 5.43 & 5.82 & 6.86 \\
\hline
\end{tabular}


Table 2b. How does the number of children for married women affect the probability of being divorced at certain ages (Austria 1981-1985)?

Proportions Divorced at ages $30,40,50$ (in percent)

Status at age 25

\begin{tabular}{lcccc} 
Age & $\begin{array}{c}\text { Married, } \\
\text { no children }\end{array}$ & $\begin{array}{c}\text { Married, } \\
1 \text { child }\end{array}$ & $\begin{array}{c}\text { Married, } \\
2 \text { children }\end{array}$ & $\begin{array}{c}\text { Married, } \\
3+\text { children }\end{array}$ \\
30 & 4.63 & 3.75 & 2.75 & 3.43 \\
40 & 9.55 & 8.55 & 7.21 & 6.38 \\
50 & 11.56 & 10.84 & 9.22 & 8.07 \\
& \multicolumn{5}{c}{ Status at age 35} \\
40 & 3.73 & 6.12 & 3.88 & 2.37 \\
50 & 8.13 & 9.85 & 6.82 & 4.70
\end{tabular}

bilities are for women with two children; larger families in Finland have again higher risks of divorce although still lower than that of childless couples. Generally the proportions of women in the divorced state are slightly higher in Austria than in Finland.

\section{How does the number of children influence proportions remarried after divorce?}

For Finnish divorcees, the presence of children influences remarriage prospects: for a childless 30 -year-old woman, the probability of being remarried at age 40 is only 0.18 whereas it is $0.32-0.35$ for women of the same age with children. In Austria the presence of children also matters for the remarriage probabilities, but the pattern is opposite that of Finland. In Austria divorced women at age 30 have the highest probability to be remarried after 10 or 20 years if they are childless $(0.53$ at age 40,0.61 at age 50) whereas the presence of two or more children brings the probabilities down to 0.33 at age 40 and 0.36 at age 50. For women aged 40 this differential becomes even wider with 44 percent of the childless women being remarried after five years but only 6 percent of the women with two or more children.

The only pattern common to Austria and Finland is that in both countries the probabilities of being remarried 10 years after being divorced are clearly higher for women aged 30 (at any parity) than for women aged 40 indicating that a younger age tends to increase the probability of remarriage after divorce.

Generally, the probabilities of being remarried are significantly higher in Austria than in Finland. This is especially true for the childless women and most extreme at age 40 where for childless women the probability of being remarried five years after being divorced is only 0.02 in Finland but 0.44 in Austria. For larger families the levels are of a similar magnitude and even somewhat greater in Finland.

From the remarriage probabilities we might infer something about the role of marriage in Austria compared to Finland. In Finland it might be socially more acceptable for a woman to live as a divorcee than in Austria. The higher remarriage probabilities for women with children in Finland is understandable in the light of the wish to give the children a "complete» family and also from an economical point of view. In Austria the much higher remarriage probabilities for childless women may indicate that it is easier for such a woman to find a new husband and/or that remarriage is a more desirable or necessary vehicle for improving socioeconomic status. 
Table 3a. How does the number of children influence remarriage after divorce (Finland 1984)?

\begin{tabular}{|c|c|c|c|}
\hline & \multicolumn{3}{|c|}{ Proportions Married at ages 40 and 50 (in percent) } \\
\hline Age & $\begin{array}{l}\text { Divorced, } \\
\text { no children }\end{array}$ & $\begin{array}{l}\text { Divorced, } \\
1 \text { child }\end{array}$ & $\begin{array}{l}\text { Divorced, } \\
2+\text { children }\end{array}$ \\
\hline $\begin{array}{l}40 \\
50\end{array}$ & $\begin{array}{l}17.67 \\
21.01\end{array}$ & $\begin{array}{l}32.14 \\
39.72\end{array}$ & $\begin{array}{l}34.78 \\
40.81\end{array}$ \\
\hline & \multicolumn{3}{|c|}{ Status at age 40} \\
\hline Age & $\begin{array}{l}\text { Divorced, } \\
\text { no child }\end{array}$ & $\begin{array}{l}\text { Divorced, } \\
1 \text { child }\end{array}$ & $\begin{array}{c}\text { Divorced, } \\
2+\text { children }\end{array}$ \\
\hline 45 & 2.27 & 10.98 & 9.62 \\
\hline 50 & 3.81 & 16.41 & 14.23 \\
\hline
\end{tabular}

Table 3b. How does the number of children influence remarriage after divorce (Austria 1981-1985)?

\begin{tabular}{|c|c|c|c|}
\hline \multicolumn{4}{|c|}{ Proportions Married at age 40 and 50 (in percent) } \\
\hline & \multicolumn{3}{|c|}{ Status at age 30} \\
\hline Age & $\begin{array}{l}\text { Divorced, } \\
\text { no children }\end{array}$ & $\begin{array}{l}\text { Divorced, } \\
1 \text { child }\end{array}$ & $\begin{array}{l}\text { Divorced, } \\
2+\text { children }\end{array}$ \\
\hline 40 & 53.14 & 40.66 & 33.14 \\
\hline 50 & 60.90 & 43.07 & 36.16 \\
\hline & \multicolumn{3}{|c|}{ Status at age 40} \\
\hline Age & $\begin{array}{l}\text { Divorced, } \\
\text { no child }\end{array}$ & $\begin{array}{l}\text { Divorced, } \\
1 \text { child }\end{array}$ & $\begin{array}{c}\text { Divorced, } \\
2+\text { children }\end{array}$ \\
\hline 45 & 43.86 & 9.54 & 6.05 \\
\hline 50 & 44.93 & 10.93 & 9.79 \\
\hline
\end{tabular}

Does a woman's family status at a given age affect the number of subsequent births within marriage?

In Finland women who are already married at age 20, but still childless, have very high average subsequent fertility. The proportion of such women who are married with one or no children at age 40 is below 5 percent; the majority of such women will have two or three children, and 30 percent will end up with four or more children. Women who have already had one child by age 20 have even higher lifetime fertility: in this group, there is an almost 40 percent chance of having four or more children by age 40 . It should be noted that the figures in Table 4 omit the fertility experience of women currently widowed or divorced at age 40 (and 50), and therefore are incomplete with respect to marital fertility. However, our figures pertain to about 90 percent of the relevant population, and hence can be expected to approximate quite closely the full cohort fertility experience.

Among women married at age 25 in Finland, the pattern is quite different, coming close to the average pattern of marital fertility: more than 40 percent of these women will have two children and about 4 percent will be still childless and married at age 40 . In the case of married women with one child by age 25 the average fertility level is somewhat higher, but still peaks at two-child families. 
A comparison of Tables $4 \mathrm{a}$ and $4 \mathrm{~b}$ reveals that with respect to this question the Finnish and Austrian patterns are quite similar, with one exception: the number of women with three or more children is substantially lower in Austria than in Finland. This not only reflects the somewhat higher level of Finnish fertility, but we may also conclude that in Finland the selectivity towards high fertility that is indicated by early marriage is much stronger than in Austria.

\section{What are the expected times to be spent in each status, given that a women} is in a specified status at a specified age?

Tables $5 \mathrm{a}$ and $5 \mathrm{~b}$ give the proportion of the remaining life up to age 50 spent, on average, in various family statuses, for selected initial statues. In Finland a childless single woman 15 years old will on the average spend 40 percent of the 35 years

Table 4a. Does a woman's family status at ages 20 and 25 affect the number of children in marriage at ages 40-50 (Finland 1984)?

Status at age 20

Married, no children Married, 1 child

Percentage in status at age 40 and 50

$\begin{array}{lccccccccc} & \text { Married, } & \text { Married, } & \text { Married, } & \text { Married, } & \text { Married, } & \text { Married, } & \text { Married, } & \text { Married, } & \text { Married, } \\ \text { Age } & \text { no children } & 1 \text { child } & 2 \text { children } & 3 \text { children } & 4+\text { children } & 1 \text { child } & 2 \text { children } & 3 \text { children } & 4+\text { children } \\ 40 & .43 & 4.26 & 29.20 & 25.44 & 29.89 & 1.61 & 22.83 & 25.15 & 39.52 \\ 50 & .37 & 3.95 & 26.93 & 23.14 & 27.63 & 1.58 & 21.27 & 22.80 & 36.16\end{array}$

Status at age 25

Married, no children

Married, 1 child

Percentage in status at age 40 and 50

\begin{tabular}{|c|c|c|c|c|c|c|c|c|c|}
\hline Age & $\begin{array}{l}\text { Married, } \\
\text { no children }\end{array}$ & $\begin{array}{l}\text { Married, } \\
1 \text { child }\end{array}$ & $\begin{array}{l}\text { Married, } \\
2 \text { children }\end{array}$ & $\begin{array}{l}\text { Married, } \\
3 \text { children }\end{array}$ & $\begin{array}{l}\text { Married, } \\
4+\text { children }\end{array}$ & $\begin{array}{l}\text { Married, } \\
1 \text { child }\end{array}$ & $\begin{array}{l}\text { Married, } \\
2 \text { children }\end{array}$ & $\begin{array}{l}\text { Married, } \\
3 \text { children }\end{array}$ & $\begin{array}{l}\text { Married, } \\
4+\text { children }\end{array}$ \\
\hline 40 & 3.72 & 16.08 & 40.76 & 19.58 & 10.04 & 7.12 & 40.60 & 26.22 & 17.62 \\
\hline 50 & 3.11 & 14.43 & 37.37 & 18.17 & 9.75 & 6.39 & 37.03 & 23.99 & 16.75 \\
\hline
\end{tabular}

Table 4b. Does a woman's family status at ages 20 and 25 affect the number of children in marriage at ages 40-50 (Austria 1981-1985)?

Status at age 20

Married, no children

Married, 1 child

Percentage in status at age 40 and 50

$\begin{array}{lccccccc}\text { Age } & \begin{array}{c}\text { Married, } \\ \text { no children }\end{array} & \begin{array}{c}\text { Married, } \\ 1 \text { child }\end{array} & \begin{array}{c}\text { Married, } \\ 2 \text { children }\end{array} & \begin{array}{c}\text { Married, } \\ \text { 3+ children }\end{array} & \begin{array}{c}\text { Married, } \\ 1 \text { child }\end{array} & \begin{array}{c}\text { Married, } \\ 2 \text { children }\end{array} & \begin{array}{c}\text { Married } \\ 3+\text { children }\end{array} \\ 40 & 2.22 & 14.49 & 40.60 & 28.71 & 8.60 & 42.05 & 35.93 \\ 50 & 2.05 & 12.97 & 39.84 & 26.60 & 7.74 & 38.11 & 33.17\end{array}$

Status at age 25

Married, no children

Married, 1 child

Percentage in status at age 40 and 50

Married, Married, Married, Married, Married, Married, Married, Age " no children 1 child 2 children 3 t children 1 child 2 children $3+$ children

$\begin{array}{llllllll}40 & 12.95 & 30.45 & 31.91 & 11.80 & 22.88 & 43.75 & 21.37 \\ 50 & 11.58 & 27.01 & 29.14 & 11.14 & 20.22 & 39.65 & 19.98\end{array}$


up to age 50 in her initial status, single and childless. Nearly 50 percent of the 35 -year period will on average be spent married, the highest proportions of which will be lived with one or two children (11 percent, and 17 percent, of the total, respectively). It is important to remember that no individual woman in Finland is expected to actually spend part of her life in each of the statuses. The figures only give averages for the total person-years of experience between ages 15 and 50, for the total female population. Hence the proportions shown can be interpreted as the proportions of time spent in various family statuses in a population governed by the observed transition intensities at all ages. Interpreted in this way, the figures are of potential interest from a social policy perspective.

For Austria the life expectancies for single women without children at age 15 look generally similar but reflect all the differences in fertility levels and proportions remaining single. While in Finland the average woman spends 47 percent of her life between 15 and 50 as unmarried, the average Austrian woman only spends 39 percent in this state. The average Finnish woman spends 15 percent of these 35 years in the married state with three or more children, the average Austrian woman only 10 percent. Generally, this indicates a somewhat higher heterogeneity of family life cycles in Finland than in Austria.

Table 5a. Life expectancies: percentage of remaining life (up to age 50) spent on the average in different family statuses given initial age and status (Finland 1984).

Initial status:

\begin{tabular}{|c|c|c|c|c|c|c|c|}
\hline $\begin{array}{l}\text { Sing } \\
\text { o ch } \\
\text { at ag }\end{array}$ & $\begin{array}{l}\text { Single, } \\
1+\text { children }\end{array}$ & $\begin{array}{l}\text { Married, } \\
\text { no children } \\
\text { at age } 20\end{array}$ & $\begin{array}{l}\text { Married, } \\
1 \text { child } \\
\text { at age } 20\end{array}$ & $\begin{array}{c}\text { Married, } \\
\text { no children } \\
\text { at age } 30\end{array}$ & $\begin{array}{c}\text { Married, } \\
1 \text { child } \\
\text { at age } 30\end{array}$ & $\begin{array}{l}\text { Single, } \\
\text { no children } \\
\text { at age } 30\end{array}$ & $\begin{array}{c}\text { Divorced, } \\
1 \text { child } \\
\text { at age } 30\end{array}$ \\
\hline
\end{tabular}

Single,

\begin{tabular}{|c|c|c|c|c|c|c|c|c|c|}
\hline no children & 40.43 & - & - & - & - & - & 63.13 & - & - \\
\hline $\begin{array}{l}\text { Single, } \\
1+\text { children }\end{array}$ & 6.13 & 40.59 & - & - & - & - & 6.65 & - & - \\
\hline $\begin{array}{l}\text { Married, } \\
\text { no children }\end{array}$ & 6.30 & - & 7.35 & - & 33.40 & - & 12.61 & - & - \\
\hline $\begin{array}{l}\text { Married, } \\
1 \text { child }\end{array}$ & 10.59 & 7.23 & 12.39 & 10.95 & 32.86 & 37.92 & 9.90 & 16.75 & 1.16 \\
\hline $\begin{array}{l}\text { Married, } \\
2 \text { children }\end{array}$ & 17.28 & 21.05 & 30.89 & 29.15 & 20.21 & 41.94 & 4.47 & 8.86 & 1.95 \\
\hline $\begin{array}{l}\text { Married, } \\
3 \text { children }\end{array}$ & 8.57 & 13.60 & 20.78 & 22.94 & 3.95 & 10.81 & .82 & 2.64 & .89 \\
\hline $\begin{array}{l}\text { Married, } \\
4+\text { children }\end{array}$ & 6.51 & 13.23 & 20.14 & 28.26 & .84 & 2.81 & .19 & .52 & .51 \\
\hline $\begin{array}{l}\text { Widowed, } \\
\text { no children }\end{array}$ & .11 & - & .11 & - & .75 & - & .29 & - & - \\
\hline $\begin{array}{l}\text { Widowed, } \\
1+\text { children }\end{array}$ & .80 & 1.03 & 1.66 & 1.74 & 1.18 & 1.72 & .31 & .56 & 95.42 \\
\hline $\begin{array}{l}\text { Divorced, } \\
\text { no children }\end{array}$ & .62 & - & .61 & - & 3.56 & - & .88 & - & - \\
\hline $\begin{array}{l}\text { Divorced, } \\
1 \text { child }\end{array}$ & .82 & .49 & 1.39 & 1.15 & 2.19 & 2.39 & .54 & 58.27 & .02 \\
\hline $\begin{array}{l}\text { Divorced, } \\
2+\text { children }\end{array}$ & 1.82 & 2.78 & 4.71 & 5.81 & 1.05 & 2.42 & .21 & 12.41 & .05 \\
\hline
\end{tabular}


Table 5b. Life expectancies: percentage of remaining life (up to age 50) spent on the average in different family statuses given initial age and status (Austria 1981-1985).

Initial status:

Single, Single, Married, Married, Married, Married, Single, Divorced, Widowed, no children $1+$ children no children 1 child no children 1 child no children 1 child 1 child at age 15 at age 20 at age 20 at age 20 at age 30 at age 30 at age 30 at age 30 at age 40

Single,

no children

33.26

Single,

$1+$ children

Married, no children

Married,

1 child

Married,

2 children

Married,

$3+$ children

9.53

5.40

16.38

9.58

15.92

17.82

20.23

36.81

21.42

19.95

25.91

0.93

4.37

0.08

no children

0.21

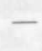

Widowed,

1 child

0.38

0.53

0.73

$-$

1.36

1.01

0.54

1.21

0.12

0.50

88.51

Widowed,

$2+$ children

0.67

1.31

1.29

1.56

0.19

0.69

0.06

0.26

0.00

Divorced, no children

Divorced,

1 child

0.92

0.97

5.28

$\begin{array}{ll}1.82 & 1.79\end{array}$

3.03

2.09

3.10

4.81

1.32

Divorced,

$2+$ children

$2.10 \quad 3.96$

4.29

5.04

0.56

1.95

0.59

45.83

0.37

$0.14 \quad 15.94$

0.00

Selectively comparing life expectancies for Finland and Austria we find the greatest difference with respect to single mothers. As already discussed above for probabilities, we find that in Finland single mothers aged 20 are expected to spend 40 percent of their life till age 50 in that state, whereas the corresponding group of Austrian women will only spend 16 percent as singles. For married women aged 30 with no child or one child the probabilities of remaining in the same state for 20 years, i.e. having no additional children (disregarding divorce) is much higher in Austria (53 percent and 60 percent) as compared to Finland ( 33 percent and 38 percent). In conjunction with this we see that for the same group of women the proportion of time spent in the status married with two children is much higher in Finland than in Austria. This indicates that marital fertility beyond age 30 is higher in Finland than in Austria.

\section{Results from the Duration-Dependent Analysis}

In this paper we devote relatively little space to the results of our duration-dependent analysis, due both to space limitations and to the fact that we have such results only for Finland, and hence cannot maintain the comparative focus of the paper. 
Table 6. Selected transition probabilities, from married at age 25 to divorced at later ages, by number of children and duration of marriage (Finland 1984).

\begin{tabular}{|c|c|c|c|c|c|c|c|c|}
\hline \multirow[b]{2}{*}{$\begin{array}{l}\text { Duration: } \\
\text { of marriage }\end{array}$} & \multicolumn{7}{|c|}{ Status at age 25} & Married, 2 childrer \\
\hline & 0 & 3 & 6 & 0 & 3 & 6 & 3 & 6 \\
\hline $\begin{array}{l}\text { Percent divorced, } \\
\text { age } 30\end{array}$ & 2.69 & 5.21 & 8.11 & 2.57 & 3.09 & 3.98 & 2.47 & 2.23 \\
\hline age 40 & 5.65 & 9.92 & 15.04 & 4.80 & 6.39 & 8.84 & 5.26 & 6.10 \\
\hline age 50 & 8.29 & 11.94 & 16.57 & 7.46 & 8.62 & 10.52 & 7.79 & 8.40 \\
\hline
\end{tabular}

The DDMSLT generates output many times larger than does the MSLT, making the problem of selecting output for discussion even larger. We have chosen to illustrate the effect of controlling for duration, with respect to one of the issues discussed previously: the effect of childbearing upon later marital experience. A more extensive discussion of such issues is given in Wolf (1988).

Table 6 presents selected transition probabilities, which can be compared to those found in the upper panel of Table $2 \mathrm{a}$. For women married at age 25 , with no children, or with 1 or 2 children, the percent divorced at ages 30,40 , and 50 are shown, according to the duration of marriage at age 25 .

The most striking findings in Table 6 pertain to childless women. For example, the probability (in percentage terms) of being divorced at age 30 varies from a low of 2.7, for women still in their first year of marriage at age 25 , to 8.1 , for women who have passed their sixth anniversary by age 25 (i.e., women who got married between their 19th and 20th birthdays). Even more extreme is the contrast between the corresponding probabilities at age 40: here, the probability for women at duration six is nearly three times that for newly-married women. The probability of being divorced at a later age depends on remarriage as well as on divorce risks. These figures may arise because divorce risks increase with marital duration, provided that the couple remains childless (something which can be verified by examination of examination of the rates themselves). Similar results have appeared in some previous studies, such as Koo and Janowitz (1983) and Wolf (1984), both of which used U.S. data. Alternatively, the results can be interpreted as evidence of the increased divorce risks associated with early marriage.

The reader should note that in this analysis we control for marital-status duration, not for birth interval; thus, for example, women married, with one child, at duration-of-marriage three years, may have had their child before or after marriage. Thus our results average over all childbearing histories. Perhaps due in art to this reason, the differentials by marital duration, for women with one and two children, are less than for childless women. Nonetheless, even these limited findings suggest the importance of isolating the effects of marital duration in a life cycle analysis.

\section{Conclusion}

In lieu of a summary of our paper, we close by pointing out several possible avenues of further work in this area. First, as noted before the MSLT has been shown to be useful in making demographic projections, and it would clearly be useful to perform disaggregated projections of the population according to marital status and 
parity. Such projections would be of value in considerations of housing markets, and for such issues as the household composition and well-being of the elderly. In the case of Austria such projections were done by Lutz and Scherbov (1989) and Aufhauser and Lutz (1987).

Another useful application of the MSLT technique is as a means of assessing the implications of changes in one or more of the underlying rate schedules. Using the models developed here, we can compute a broad range of implications of changes in marriage, divorce, or remarriage rates; of parity-specific birth rates, and of mortality rates.

Using the more general DDMSLT approach, numerous summary indicators of the family life cycle can be derived, beyond those presented above. For example, expectations of life spent in each possible status can be disaggregated according to duration category; from this, in turn, it is possible to approximate the frequency distribution of each duration-in-status variable. The mean time spent in the current status, at any selected age, can easily be computed. And, it is possible to compare the survivorship of different age-cohorts of, say, marriages, by simply reading along the appropriate diagonal entries of the $l(x)$ tables.

Finally, it would be useful to extend the comparative focus of this analysis, using comparable data from additional countries. Countries in which large-scale household surveys (or micro-censuses) are conducted - and in which marital and fertilityhistory data are collected - and countries in which population registration systems are implemented, are likely candidates for such a comparative analysis.

By comparing Austria and Finland, this paper revealed significant differences in the family-related life cycles of women that, on the one hand, point to different historically-based societal and cultural environments and, on the other hand, have implications for differential future family and household structures in the two countries.

\section{Acknowledgements}

The study on which this paper is based was in part supported by Grant No. P6006 of the Austrian Science Foundation. The authors want to thank Andreas Bakany for his able research assistance and Mauri Nieminen (Central Statistical Office of Finland, Helsinki) and Elisabeth Aufhauser (Institut für Demographie, Vienna) for their cooperation in providing us with the data. An earlier version of this paper was presented at the European Population Conference 1987 in Jyväskylä, Finland.

\section{References}

Aufhauser, E. and Lutz, W. (1987) Demographische Analyse des Familienbezogenen Lebenszyklus österreichischer Frauen. Vienna: Institut für Demographie.

Espenshade, T. J. (1986) Markov chain models of marital event histories. In: Current Perspectives on Aging and the Life Cycle, Volume 2, pp. 73-106. Greenwich, Conn.: JAI.

Glick, P. (1957) American Families. New York: Wiley.

Glick, P. (1977) Updating the lifecycle of the family. Journal of Marriage and the Family 39(1): 5-25.

Haslinger, A. (1981) Ehe ohne Trauschein. Demographische Informationen 2: 13-35.

Keilman, N. (1987) Recent trends in family and household composition in Europe. European Journal of Population 3(3/4): 297-326.

Keyfitz, N. (1985) Applied Mathematical Demography. 2nd edition. New York: Springer-Verlag.

Koo, H. P. and Janowitz, B. K. (1983) Interrelationships between family and marital dissolution: results of a simultaneous logit model. Demography 20(2): 129-146. 
Kytir, J. and Münz, R. (1986) Illegitimacy in Austria. Demographische Informationen 1986, pp. 7-21.

Lutz, W. (1985) Heiraten, Scheidungen und Kinderzahl: Demographische Tafeln zum Familien-Lebenszyklus in Österreich. Demographische Informationen 1985, pp. 3-20.

Lutz, W. and Scherbov, S. (1989) Multi-state Analysis of Family Dynamics in Austria: Scenarios to the Year 2030. Forthcoming Working Paper. Laxenburg, Austria: International Institute for Applied Systems Analysis.

Rajulton, F. (1985) Heterogeneous marital behavior in Belgium, 1970 and 1977: an application of the semi-Markov model to period data. Mathematical Biosciences 73: 197-225.

Rogers, A. and Willekens, F. (eds.) (1986) Migration and Settlement: a Multiregional Comparative Study. Dordrecht: D. Reidel Publishing Co.

Suchindran, C. M.; Namboodiri, N. K. and West K. (1977) Analyses of fertility by increment-decrement life tables. In: Proceedings of the American Statistical Association, Social Statistics Section 1, pp. $431-436$.

Suchindran, C. M. and Koo, H. (1980) Divorce, Remarriage, and Fertility. Paper presented at the annual meetings of the Population Association of America, Denver, Colorado.

Wijewickrema, S. and Alii (1984) Marital status trends in Belgium (1961-1977): application of multistate analysis. In: Population and Family in Low Countries, IV, pp. 47-72. Voorburg: Netherlands Interuniversity Demographic Institute.

Willekens, F.; Shah, I.; Shah, J. M. and Ramachandran, P. (1982) Multi-state analysis of marital status life tables: theory and application. Population Studies 36(1): 129-144.

Wolf, D. (1984) Fertility and marital dissolution: least squares estimates of a dynamic model. Chapter 3 of Models of Marital and Fertility Dynamics, Report submitted to the U.S. National Institute of Child Health and Human Development by the Urban Institute.

Wolf, D. (1986) Simulation models for analyzing continuous-time event-history models. In: Sociological Methodology, Volume 16, edited by Nancy Tuma, pp. 283-308. San Fransisco: Jossey-Bass.

Wolf, D. (1988) The multistate life table with duration dependence. Mathematical Population Studies $1 / 3: 217-246$. 